\title{
Faktor - Faktor Risiko Kejadian Malfungsi Pirau Ventrikuloperitoneal Pada Pasien Hidrosefalus Bayi Dan Anak Di Rumah Saikit Umum Pendidikan dr. Sardjito Yogyakarta
}

\author{
${ }^{1}$ Yoyok Subagio, ${ }^{2} \mathrm{H}$ andoyo Pramusinto, ${ }^{2}$ Endro Basuki \\ ${ }^{1}$ Dokter Bedah Saraf Rumah Sakit Universitas Muhammadiyah Malang \\ J1. Raya Tlogomas No.45, Tlogomas, Lowokwaru, Kota Malang \\ 2Divisi Bedah Saraf FKKMK Universitas Gadjah Mada \\ J1. Farmako, Senolowo, Sekip Utara, Depok, Sleman, Daerah Istimewa Yogyakarta \\ Email : yoyoksbg27@gmail.com
}

Diterima : 27 Februari 2019. Perbaikan : 4 April 2019. Diterbitkan : 29 Juni 2019.

DOI : https://doi.org/10.22219/sm.Vol15.SMUMM1.8624

\begin{abstract}
ABSTRAK
Kasus hidrosefalus pada bayi dan anak, merupakan salah satu kasus yang sering terjadi dan mempunyai komplikasi yang bervariasi. Penanganan hidrosefalus adalah dilakukan pemasangan pirau ventrikuloperitoneal. Tindakan tersebut sering ditemukan komplikasi, diantaranya adalah malfungsi. Faktor yang mempengaruhi terjadinya malfungsi tersebut, salah satunya berupa karakteristik pasien, cara persalinan, analisa CSS, tipe dan tekanan pirau ventrikuloperitoneal, jenis hidrosefalus, dan etiologi hidrosefalus. Penulis dalam kesempatan ini akan menganalisa faktor - faktor yang berpengaruh terhadap kejadian malfungsi pirau ventrikuloperitoneal. Penelitian ini adalah penelitian analitik dengan desain cohort retrospective, yaitu dengan cara mengambil sampel pasien hidrosefalus pada bayi dan anak yang telah dilakukan pemasangan pirau ventrikuloperitoneal pada periode Januari 2015 sampai dengan Desember 2016. Jumlah sampel yang akan diteliti adalah sebesar 124 sampel. Data dianalisis dengan Chi square yang selanjutnya dilakukan analisis multivariat dengan regresi logistik. Total sampel penelitian 124 pasien hidrosefalus pada bayi dan anak yang sesuai dengan kriteria inklusi. Dilakukan pengambilan sampel secara total. Pada penelitian ini terdapat 8 faktor risiko yang dapat mempengaruhi kejadian malfungsi pirau ventrikuloperitoneal pada pasien hidrosefalus bayi dan anak Pada analisis multivariat terpilih 3 faktor risiko yang dapat mempengaruhi kejadian malfungsi pirau ventrikuloperitoneal, yaitu usia kehamilan, usia kehamilan, tipe pirau ventrikuloperitoneal, dan analisa jumlah sel CSS. Faktor risiko yang dominan dan berpengaruh terhadap kejadian malfungsi pirau ventrikuloperitoneal pada pasien hidrosefalus bayi dan anak adalah usia kehamilan preterm, yaitu sebanyak 6 sampel (66,7\%) dari 9 sampel dengan nilai $\mathrm{p}=0,010$ yang artinya nilai $\mathrm{p}<0,05$ dan dengan $O d d$ s Ratio $(\mathrm{OR})$ paling besar yaitu 7,156 dengan IK 95\% (1,627-31,476), sedangkan jumlah sel CSS yang meningkat sebesar 8 sampel (38,1\%) dari 21 sampel dan nilai $\mathrm{p}=0,406$ dan OR 1,646 dengan IK 95\% (0,509-5,328). Untuk tipe pirau ventrikuloperitoneal mempunyai nilai $\mathrm{p}=0,161$ dan OR 0,727 dengan IK 95\% (0,466-1,136). Usia kehamilan preterm pada pasien hidrosefalus bayi dan anak merupakan faktor risiko yang dapat mempengaruhi kejadian malfungsi pirau ventrikuloperitoneal di RSUP Dr. Sardjito.
\end{abstract}

Kata Kunci : Hidrosefalus pada bayi dan anak, pirau ventrikuloperitoneal, malfungsi. 


\begin{abstract}
The case of bydrocephalus in infants and children, is one of the most frequent cases and has varying complications. Handling of hydrocephalus is performed by ventriculoperitoneal shunting. These actions are often found complications, including malfunctions. Factors affecting the occurrence of such malfunctions, one of which is patient characteristics, mode of delivery, CSS analysis, ventriculoperitoneal shunt type and pressure, bydrocephalus type, and hydrocephalus etiology. The writer on this occasion will analyze the factors that affect the incidence of ventriculoperitoneal shunt malfunction. This research is an analytic research with retrospective cohort design that is by taking samples of hydrocephalus patients in infants and children who have done ventriculoperitoneal shunting instances in the period of January 2015 until December 2016. The number of samples to be studied is 124 samples. The data were analyzed by chi square which then performed multivariate analysis with logistic regression. Total study sample of 124 bydrocephalus patients in infants and children according to the inclusion criteria. Total sampling was taken. In this study, there were 8 risk factors that could influence the occurrence of ventriculoperitoneal shunting malfunction in infant and children bydrocephalus patients subsequently performed multivariate anaisis and selected 3 risk factors that could affect the incidence of ventriculoperitoneal shunt malfunction, ie gestational age, gestational age, ventriculoperitoneal shunt type, and analysis of CSS cell numbers. The dominant risk factor and effect on the occurrence of ventriculoperitoneal shunt malfunction in infant and child bydrocephalus patients was preterm, ie 6 samples (66,7\%) from 9 samples with $p$ value $=0,010$ which means $p$ value $<0,05$ and with Odds Ratio (OR) was highest at 7,156 with 95\% IK (1,627-31,476), while the number of CSS cells increased by 8 samples (38,1\%) from 21 samples and $p$ value $=0,406$ and OR 1,646 with IK 95\% 0,509-5,328). Whereas for ventriculoperitoneal shunt type have value $p=0,161$ and OR 0,727 with IK 95\% (0,466-1,136). The age of preterm pregnancy in patients with infant and child hydrocephalus is a risk factor that may affect the incidence of ventriculoperitoneal shunt malfunction in Dr. Sardjito.
\end{abstract}

Key words : Hidrocephalus in infants and children, ventriculoperitoneal shunt, malfunction

\title{
PENDAHULUAN
}

Hidrosefalus merupakan kondisi dimana terjadi ketidakseimbangan antara produksi cairan serebrospinal (CSS) dengan penyerapannya. Jumlah kasus hidrosefalus di dunia cukup bervariasi. Di Negara Amerika Serikat kejadian hidrosefalus dijumpai sekitar 0,5-4 per 1000 kelahiran hidup. Insidensi hidrosefalus antara 0,2 - 4 setiap 1000 kelahiran. Di Jepang kejadian hidrosefalus 0,2 per 1000 kelahiran. Di Indonesia kasus hidrosefalus mencapai kurang lebih 2 kasus dalam 1000 kelahiran ${ }^{1}$. Hidrosefalus dibagi dalam 2 kategori, yaitu komunikan dan non komunikan². Penanganan pasien hidrosefalus telah dimulai sejak tahuan 1950 dengan dilakukannya pemasangan pirau ventrikuloperitoneal. Kejadian malfungsi pirau ventrikuloperitoneal di beberapa tempat menunjukkan angka $40-60 \%$ dalam setahun. Faktor yang berkaitan dengan malfungsi pirau ventrikuloperitoneal meliputi jenis kelamin, umur pasien, jenis pirau ventrikuloperitoneal yang digunakan, jenis hidrosefalus, dokter bedah (operator) dan juga faktor perioperatif. Malfungsi ini dapat terjadi langsung setelah dilakukan tindakan pemasangan sampai dengan 1 tahun setelah pemasangan (Al-Tamimi YZ. et al., 2014, Tuli S. et al., 2000). Salah satu prediktor penting terjadinya malfungsi pirau ventrikuloperitoneal adalah usia saat pertama kali pasien dilakukan pemasangan (Tuli S. et al., 2000, Park M-K. et al., 2015, Buster BE. et al., 2016, Rui K. et al. 2011, Tisell M. 2009). Faktor usia saat pertama kali pemasangan pirau ventrikuloperitonealmerupakan salah satu faktor terjadinya malfungsi pirau ventrikuloperitoneal (Tamber MS. et al., 2014), sedangkan terkait dengan etiologi hidrosefalus, menurut Mcgirt et al. tidak terdapat hubungan yang signifikan terhadap terjadinya malfungsi pirau ventrikuloperitoneal. Tindakan operasi pemasangan pirau 
ventrikuloperitoneal di RSUP Dr. Sardjito sendiri tidak terlepas dengan adanya komplikasi yang timbul akibat tindakan yang dilakukan. Malfungsi merupakan komplikasi yang sering timbul. Tidak ada data pasti terkait kejadian malfungsi dan infeksi pada pasien hidrosefalus yang telah dilakukan pemasangan pirau ventrikuloperitoneal di RSUP Dr. Sardjito, begitu juga dengan faktor yang menyebabkan terjadinya malfungsi pirau ventrikuloperitoneal.

\section{METODE PENELITIAN}

Penelitian ini adalah penelitian analitik dengan menggunakan desain Cohort retrospective study. Dalam penelitian ini, peneliti tetap membandingkan kelompok yang terpapar dan yang tidak terpapar (Browd SR. et al., 2006) Tempat penelitian dilakukan di bagian Instalasi Catatan Medis RSUP Dr. Sardjito Yogyakarta pada minggu ketiga bulan Oktober 2017 sampai dengan November 2017. Populasi yang digunakan adalah semua pasien hidrosefalus pada bayi dan anak di RSUP Dr. Sardjito yang telah dilakukan pemasangan pirau ventrikuloperitoneal pada Januari 2015 sampai dengan Desember 2016. Kriteria inklusi pada penelitian ini adalah: (1) pasien hidrosefalus pada bayi dan anak - anak di RSUP Dr. Sardjito yang telah dibuktikan dengan hasil pemeriksaan klinis dan radiologi (USG kepala, CT Scan Kepala, MRI kepala), (2) semua pasien hidrosefalus pada bayi dan anak - anak yang telah dilakukan pemasangan pirau ventrikuloperitoneal di RSUP Dr. Sardjito, (3) semua pasien hidrosefalus pada bayi dan anak yang telah dilakukan tindakan revisi pemasangan pirau ventrikulperitoneal di RSUP Dr. Sardjito, (4) Tidak ada riwayat diversi CSS sebelumnya selain menggunakan pirau ventrikuloperitoneal. Sedangkan untuk kriteria eksklusi adalah: (1) pasien hidrosefalus pada bayi dan anak-anak yang pernah dilakukan pemasangan pirau ventrikuloperitoneal dengan gangguan penyerapan intraabdominal, (2) Pasien hidrosefalus pada bayi dan anak - anak yang mengalami infeksi pada luka operasi setelah dilakukan pemasangan pirau ventrikuloperitoneal, (3) Pasien hidrosefalus bayi dan anak yang telah dilakukan pemasangan pirau ventrikuloperitoneal yang mengalami gangguan sistemik berat setelah dilakukan pemasangan. Sampel penelitian yang didapatkan dari data catatan medis pasien yang sesuai dengan kriteria inklusi adalah sebesar 124 sampel dan pengambilan dilakukan secara total sampling. Analisa data sendiri dilakukan dengan menggunakan analisis Chi square dengan SPSS 17 for windows.

\section{HASIL PENELITIAN}

Penelitian telah dilakukan di bagian Instalasi Catatan Medis RSUP Dr. Sardjito Yogyakarta pada tanggal 27 Oktober 2017 sampai dengan tanggal 3 November 2017. Peneliti telah melakukan pengumpulan data dari catatan medis pasien sebanyak 124 yang memenuhi kriteria inklusi sebagai subyek penelitian dan dilakukan pengambilan sampel secara total sampling. Berdasarkan data karateristik pada tabel 1 pasien hidrosefalus pada bayi dan anak yang dilakukan pemasangan pirau 
ventrikuloperitoneal, tampak bahwa jenis kelamin laki - laki dan perempuan memiliki jumlah sampel yang sama yaitu masing - masing sebesar 62 sampel (50\%). Dari data umur tampak rerata umur pasien hidrosefalus pada bayi dan anak dalam penelitian ini adalah 3,68 $\pm 4,73$ tahun. Cara persalinan mayoritas dengan cara pervaginam, yaitu sebesar 85 sampel (68,5\%) dan sisanya dengan cara seksio sesarea. Sedangkan rerata lingkar kepala pasien hidrosefalus bayi dan anak adalah $45,08 \pm 5,09 \mathrm{~cm}$.

Tabel 1. Karakteristik pasien Hidrosefalus pada bayi dan anak di RSUP Dr.Sardjito yang dilakukan pemasangan pirau ventrikuloperitoneal

\begin{tabular}{|c|c|c|c|}
\hline No & Karakteristik & Jumlah & Presentase $(\%)$ \\
\hline \multirow[t]{3}{*}{1} & Jenis kelamin & & \\
\hline & Laki - laki & 62 & $50 \%$ \\
\hline & Perempuan & 62 & $50 \%$ \\
\hline \multirow[t]{7}{*}{2} & Usia & & \\
\hline & $<1$ tahun & 59 & $47,6 \%$ \\
\hline & $1-5$ tahun & 28 & $22,6 \%$ \\
\hline & $6-11$ tahun & 25 & $20,2 \%$ \\
\hline & $12-17$ tahun & 12 & $9,7 \%$ \\
\hline & Minimal 14 hari, maksimal 17 tahun & & \\
\hline & Rerata usia $3,68 \pm 4,73$ & & \\
\hline \multirow[t]{3}{*}{3} & Cara persalinan & & \\
\hline & Pervaginam & 85 & $68,5 \%$ \\
\hline & Seksio sesaria & 39 & $31,5 \%$ \\
\hline \multirow[t]{5}{*}{4} & Lingkar Kepala & & \\
\hline & $32-40$ & 24 & $19,35 \%$ \\
\hline & $41-50$ & 77 & $62,10 \%$ \\
\hline & $51-58$ & 23 & $18,55 \%$ \\
\hline & Rerata lingkar kepala $45,08 \pm 5,09 \mathrm{~cm}$ & & \\
\hline
\end{tabular}

Distribusi faktor - faktor yang dapat mempengaruhi kejadian malfungsi pirau ventrikuloperitoneal pada pasien hidrosefalus bayi dan anak dalam penelitian ini tampak dala tabel dibawah ini : 
Tabel 2. Distribusi faktor - faktor risiko yang dapat mempengaruhi kejadian malfungsi pirau ventrikuloperitoneal pada pasien hidrosefalus bayi dan anak di RSUP Dr. Sardjito.

\begin{tabular}{|c|c|c|c|c|c|c|c|}
\hline \multirow{2}{*}{ Faktor Risiko } & \multirow{2}{*}{ Jumlah } & \multicolumn{2}{|c|}{ Malfungsi } & \multirow{2}{*}{ OR } & \multicolumn{2}{|c|}{ IK 95\% } & \multirow{2}{*}{$\begin{array}{l}\text { Nilai } \\
\mathrm{p}\end{array}$} \\
\hline & & $\mathrm{Ya}$ & Tidak & & Min & Mak & \\
\hline \multicolumn{8}{|l|}{ 1. Jenis Kelamin: } \\
\hline Laki - laki & $62(50 \%)$ & $\begin{array}{c}18 \\
(29,03 \%)\end{array}$ & $\begin{array}{c}44 \\
(70,97 \%)\end{array}$ & \multirow{2}{*}{$\begin{array}{l}0,70 \\
5\end{array}$} & \multirow{2}{*}{0,290} & \multirow{2}{*}{1,714} & \multirow{2}{*}{0,440} \\
\hline Perempuan & $62(50 \%)$ & $16(25,8 \%)$ & $46(74,2 \%)$ & & & & \\
\hline \multicolumn{8}{|l|}{ 2. Jenis Hidrosefalus: } \\
\hline Komunikan & $32(25,8 \%)$ & $\begin{array}{c}10 \\
(31,25 \%)\end{array}$ & $\begin{array}{c}22 \\
(68,75 \%)\end{array}$ & \multirow{2}{*}{$\begin{array}{c}0,90 \\
0\end{array}$} & \multirow{2}{*}{0,338} & \multirow{2}{*}{2,394} & \multirow{2}{*}{0,833} \\
\hline Obstruksi & $92(74,2 \%)$ & $\begin{array}{c}24 \\
(26,09 \%) \\
\end{array}$ & $\begin{array}{c}68 \\
(73,91 \%) \\
\end{array}$ & & & & \\
\hline \multicolumn{8}{|l|}{$\begin{array}{l}\text { 3. Etiologi } \\
\text { Hidrosefalus: }\end{array}$} \\
\hline Pasca Perdarahan & $9(7,25 \%)$ & $1(11,1 \%)$ & $8(88,9 \%)$ & \multirow{8}{*}{$\begin{array}{c}0,97 \\
7\end{array}$} & \multirow{8}{*}{0.783} & \multirow{8}{*}{1,220} & \multirow{8}{*}{0,840} \\
\hline $\begin{array}{l}\text { Tumor Fossa } \\
\text { posterior }\end{array}$ & $23(18,5 \%)$ & $9(39,13 \%)$ & $\begin{array}{c}14 \\
(60,87 \%) \\
\end{array}$ & & & & \\
\hline $\begin{array}{l}\text { Stenosis } \\
\text { Akuaduktus Silvii }\end{array}$ & $23(18,5 \%)$ & $6(26,08 \%)$ & $\begin{array}{c}17 \\
(73,92 \%) \\
\end{array}$ & & & & \\
\hline $\begin{array}{l}\text { Perdarahan } \\
\text { Subarakhnoid }\end{array}$ & $4(3,22 \%)$ & $0(0 \%)$ & $4(100 \%)$ & & & & \\
\hline Infeksi CMV & $33(26,6 \%)$ & $11(33,3 \%)$ & $22(66,7 \%)$ & & & & \\
\hline Kongenital & $18(14,5 \%)$ & $4(22,2 \%)$ & $14(77,8 \%)$ & & & & \\
\hline $\begin{array}{l}\text { Tumor } \\
\text { Intraventrikel }\end{array}$ & $11(8,9 \%)$ & $2(18,2 \%)$ & $9(81,8 \%)$ & & & & \\
\hline $\begin{array}{l}\text { Tumor } \\
\text { Cranioparingioma }\end{array}$ & $3(2,41 \%)$ & $1(33,3 \%)$ & $2(66,7 \%)$ & & & & \\
\hline \multicolumn{8}{|l|}{$\begin{array}{l}\text { 4. Tipe Pirau } \\
\text { Ventrikuloperitone } \\
\text { al: }\end{array}$} \\
\hline C Rendah & $62(50 \%)$ & $16(25,8 \%)$ & $46(74,2 \%)$ & \multirow{6}{*}{$\begin{array}{c}0,72 \\
7\end{array}$} & \multirow{6}{*}{0,466} & \multirow{6}{*}{1,136} & \multirow{6}{*}{0,161} \\
\hline C Sedang & $10(8,1 \%)$ & $5(50 \%)$ & $5(50 \%)$ & & & & \\
\hline B Rendah & $17(13,7 \%)$ & $7(41,2 \%)$ & $10(58,8 \%)$ & & & & \\
\hline B Sedang & $29(23,4 \%)$ & $6(20,7 \%)$ & $23(79,3 \%)$ & & & & \\
\hline A Rendah & $5(4,03 \%)$ & $0(0 \%)$ & $5(100 \%)$ & & & & \\
\hline A Sedang & $1(0,8 \%)$ & $0(0 \%)$ & $1(100 \%)$ & & & & \\
\hline \multicolumn{8}{|l|}{$\begin{array}{l}\text { 5. Analisa Jumlah Sel } \\
\text { CSS: }\end{array}$} \\
\hline Normal & $\begin{array}{c}103 \\
(83,1 \%)\end{array}$ & $26(25,2 \%)$ & $77(74,8 \%)$ & $\begin{array}{c}1,64 \\
6\end{array}$ & 0,509 & 5,328 & 0,229 \\
\hline Meningkat & $21(16,9 \%)$ & $8(38,1 \%)$ & $13(61,9 \%)$ & & & & \\
\hline \multicolumn{4}{|l|}{ 6. Tes None-Pandy: } & & & & \\
\hline Negatif & $73(58,9 \%)$ & $17(23,3 \%)$ & $56(76,7 \%)$ & $\begin{array}{l}1,29 \\
0\end{array}$ & 0,492 & 3,251 & 0,217 \\
\hline Positif & $51(41,1 \%)$ & $17(33,3 \%)$ & $34(66,7 \%)$ & & & & \\
\hline 7. Usia Kehamilan: & & & & & & & \\
\hline Aterm & $\begin{array}{c}115 \\
(92,7 \%)\end{array}$ & $28(24,3 \%)$ & $87(75,3)$ & 7,47 & 1,627 & 34,33 & 0,010 \\
\hline Preterm & $9(7,3 \%)$ & $6(66,7 \%)$ & $3(33,3 \%)$ & & & & \\
\hline 8. Cara Persalinan: & & & & & & & \\
\hline Pervaginam & $85(68,5 \%)$ & $24(28,2 \%)$ & $61(71,8 \%)$ & 1,20 & 0,447 & 3,251 & 0,713 \\
\hline
\end{tabular}




\begin{tabular}{|c|c|c|c|c|c|c|c|}
\hline \multirow{2}{*}{ Faktor Risiko } & \multirow{2}{*}{ Jumlah } & \multicolumn{2}{|c|}{ Malfungsi } & \multirow{2}{*}{ OR } & \multicolumn{2}{|c|}{ IK 95\% } & \multirow{3}{*}{$\begin{array}{c}\text { Nilai } \\
\text { p }\end{array}$} \\
\hline & & $\mathrm{Ya}$ & Tidak & & Min & Mak & \\
\hline Seksio Sesarea & $39(31,5 \%)$ & $10(25,7 \%)$ & $29(74,3 \%)$ & 5 & & & \\
\hline
\end{tabular}

Pada tabel tersebut di atastampak jenis kelamin, laki - laki dan perempuan dalam penelitian ini mempunyai jumlah sama yaitu masing - masing sebesar 62 sampel dengan kejadian malfungsi 18 sampel (29,03\%) untuk laki-laki dan 16 sampel (25,8\%) untuk perempuan, jenis hidrosefalus meliputi komunikan dan obstruksi masing-masing 32 sampel (25,8\%) dan 92 sampel (74,2\%) dengan kejadian malfungsi 10 sampel (31,25\%) dan 24 sampel (26,09\%). Untuk etiologi hidrosefalus dalam penelitian ini yang terbanyak adalah infeksi CMV sebesar 33 sampel (26,6\%) dengan kejadian malfungsi sebesar 11 sampel (33,3\%), tumor fossa posterior sebesar 23 sampel (18,5\%) dengan kejadian malfungsi 9 sampe (39,13\%), stenosis akuaduktus silvii sebesar 23 sampel (18,5\%) dengan kejadian malfungsi 6 sampel (26,1\%), kongenital sebesar 18 sampel ( 14,5\%) dengan kejadian malfungsi 4 sampel (22,2\%), untuk tumor intraventrikel dan tumor cranioparingioma masingmasing sebesar 11 sampel (8,9\%) dan 3 sampel (2,41\%) dengan kejadian malfungsi 2 sampel $(18,2 \%)$ untuk tumor intraventrikel dan 1 sampel (33,3\%) untuk tumor cranioparingioma, dan untuk etiologi pasca perdarahan (stroke, trauma kepala) dan perdarahan subarakhnoid masing masing sebesar 9 sampel (7,25\%) dengan kejadian malfungsi 1 sampel $(11,1 \%)$ dan 4 sampel $(3,22 \%)$ dan tidak terdapat kejadian malfungsi. Untuk tipe pirau ventrikuloperitoneal yang digunakan dalam penelitian ini paling banyak adalah tipe C rendah yaitu sebesar 62 sampel (50\%) dengan kejadian malfungsi 16 sampel (25,8\%), sisanya menggunakan tipe C sedang 10 sampel (8,1\%), tipe B rendah 17 sampel (13,7\%), tipe B sedang 29 sampel (23,4\%), tipe A rendah 5 sampel (4,03\%), dan tipe A sedang 1 sampel (0,8\%). Faktor lainnya adalah analisa CSS yang meliputi jumlah sel normal sebesar 103 sampel (83,1\%) dengan kejadian malfungsi 26 sampel (25,2\%) dan jumlah sel meningkat sebesar 21 sampel (16,9\%) dengan kejadian malfungsi 8 sampel (38,1\%). Selain analisa jumlah sel, dlam penelitian ini juga dilakukan analisa terhadap tes none-pandy pada CSS dengan hasil tes negatif sebesar 73 sampel (58,9\%) dengan kejadian malfungsi 17 sampel (23,3\%), sedangkan hasi tes positif sebesar 51 sampel (41,1\%) dengan kejadian malfungsi 17 sampel (33,3\%). Sedangkan untuk faktor riwayat usia kehamilan yang meliputi usia kehamilan aterm dan preterm, masing - masing memiliki sampel sebesar 115 (92,7\%) dengan kejadian malfungsi 28 sampel $(24,3 \%)$ dan 9 sampel $(7,3 \%)$ dengan kejadian malfungsi 6 sampel (66,7\%). Pada penelitian ini dilakukan analisa tes Chi Square dengan tabel 2x2 untuk menentukan fakto - faktor yang mempengaruhi kejadian malfungsi pirau ventrikuloperitoneal yang selanjutnya dilakukan analisis multivariat dengan regersi logistik dan telah terlampir dalam tabel 3. 
Tabel 3. Hasil analis multivariat dengan regresi logistik

\begin{tabular}{|c|c|c|c|c|c|c|c|c|}
\hline \multirow{2}{*}{ Faktor Risiko } & \multirow{2}{*}{ Koefisien } & \multirow{2}{*}{$\begin{array}{l}\text { Standar } \\
\mathrm{t} \text { Error }\end{array}$} & \multirow{2}{*}{ Wald } & \multirow{2}{*}{ df } & \multirow{2}{*}{$\begin{array}{c}\text { Nilai } \\
\text { p }\end{array}$} & \multirow{2}{*}{ OR } & \multicolumn{2}{|c|}{ IK 95\% } \\
\hline & & & & & & & Min & Mak \\
\hline 1. Usia Kehamilan & 1,968 & 0,756 & 6,780 & 1 & 0,009 & $\begin{array}{c}7,15 \\
6\end{array}$ & $\begin{array}{c}1,62 \\
7\end{array}$ & 31,476 \\
\hline $\begin{array}{l}\text { 2. Tipe Pirau } \\
\text { Ventrikuloperiotone } \\
\text { al }\end{array}$ & $-0,290$ & 0,222 & 1,711 & 1 & 0,191 & $\begin{array}{c}0,74 \\
8\end{array}$ & $\begin{array}{c}0,48 \\
4\end{array}$ & 1,156 \\
\hline 3. Analisa CSS & $-0,660$ & 0,528 & 1,565 & 1 & 0,211 & $\begin{array}{c}0,51 \\
7 \\
\end{array}$ & $\begin{array}{c}0,18 \\
4 \\
\end{array}$ & 1,454 \\
\hline 4. Konstanta & $-1,816$ & 1,044 & 3,028 & 1 & 0,082 & $\begin{array}{c}0,16 \\
3\end{array}$ & & \\
\hline
\end{tabular}

Faktor risiko usia kehamilan preterm denagn nilai $\mathrm{p}=0,010$ yang artinya nilai $\mathrm{p}<0,05$ dan dengan Odds Ratio (OR) paling besar yaitu 7,156 dengan IK 95\% (1,627-31,476).

\section{PEMBAHASAN}

Pada penelitian ini faktor usia kehamilam preterm yang paling dominan dan berpengaruh secara signifikan terhadap kejadian malfungsi pirau ventrikuloperitoneal pada pasien hidrosefalus bayi dan anak seperti yang tampak pada hasil analisis multivariat dengan regresi logistik. Hal ini sesuai dengan penelitian Khan et al (2013) yang dalam penelitiannya menyebutkan faktor yang berpengaruh terhadap kejadian malfungsi pirau ventrikuloperitoneal salah satunya adalah riwayat usia kehamilan preterm. Menurut Khan et al, bayi yang dilahirkan dengan riwayat usia kehamilan preterm memiliki karakteristik berbeda pada perkembangan jaringan otak, dimana white matter mengalami keterlambatan pembentukan, jaringan otak yang mudah rusak, dan pada sistem gastrointestinal sering terdapat gangguan penyerapan CSS.Hidrosefalus pada bayi preterm akan mengakibatkan periventricle lenkomalacia, proses ini dapat mengakibatkan reaksi inflamasi yang disertai dengan peningkatan Vascular Endothelial Growth Factor (VGEF), IL-6, IL-10, dan Transforming Growth Factor- $\beta 1$ (TGF- $\beta 1$ ). Hal ini mengakibatkan peningkatan konsentrasi dari CSS (Heep, A. et al., 2004) Selain gangguan perkembangan otak, pada bayi preterm sering mengalami gangguan sistemik dan metabolik, misalnya adanya gangguan respirasi, gangguan sistem kardiovaskuler, gangguan elektrolit, gangguan sistem hepatobilier, dan hormonal (Buonocore, G. et al., 2012). Pasien hidrosefalus bayi dan anak dengan riwayat usia kehamikan preterm memiliki kecenderungan 7,15 kali terjadi malfungsi pirau ventrikuloperitoneal dibandingkan pada pasien bayi dan anak dengan riwayat usia kehamilan aterm. 


\section{KESIMPULAN}

Usia kehamilan preterm pada pasien hidrosefalus bayi dan anak merupakan faktor risiko yang dapat mempengaruhi kejadian malfungsi pirau ventrikuloperitoneal di RSUP Dr. Sardjito.

\section{DAFTAR PUSTAKA}

Al-Tamimi YZ, Sinha P, Chumas PD, Crimmins D, Drake J, Kestle J. Ventriculoperitoneal shunt 30-day failure rate: A retrospective international cohort study. Neurosurgery. 2014;74(1):29_ 34.

Browd SR, Ragel BT, Gottfried ON, Kestle JRW. Failure of cerebrospinal fluid shunts: Part I: Obstruction and mechanical failure. Pediatr Neurol. 2006;34(2):83-92.

Buonocore, G., Bracci, R. \& Weindling, M., 2012. Neonatology, Available at: http:/ /link.springer.com/10.1007/978-88-470-1405-3.

Buster BE, Bonney PA, Cheema AA, Glenn CA, Conner AK, Safavi-Abbasi S. Proximal ventricular shunt malfunctions in children: Factors associated with failure. J Clin Neurosci [Internet]. 2016;24:94-8.

Heep, A. Stoffel-Wagner, Birgit. Bartmann, Peter. Benseler, Susanne. Schaller, Carlo. Groneck, Peter. Obladen, Michael. Felderhoff-Mueser, Ursula, 2004. Vascular endothelial growth factor and transforming growth factor- $\beta 1$ are highly expressed in the cerebrospinal fluid of premature infants with posthemorrhagic hydrocephalus. Pediatric Research, 56(5), pp.768774.

Khan, F. Shamim, Muhammad Shahzad. Rehman, Abdul. Bari, Muhammad. Ehsan., 2013. Analysis of factors affecting ventriculoperitoneal shunt survival in pediatric patients. , pp.791-802.

Mardani. Universitas sumatera utara. Igarss 2014. 2014;(X):1-5.

Mcgirt MJ, John JL, Iii CW, Villavicencio AT, Hopkins JS, Fuchs HE. Cerebrospinal Fluid Shunt Survival and Etiology of Failures : A Seven-Year Institutional Experience. 2002;27710:24855.

Nielsen N, Breedt A. Nadine Nielsen and Amanda Breedt 2 2.1. 2013.

Park M-K, Kim M, Park K-S, Park S-H, Hwang J-H, Hwang SK. A retrospective analysis of ventriculoperitoneal shunt revision cases of a single institute. J Korean Neurosurg Soc [Internet]. 2015;57(5):359-63.

Rocco C Di, Turgut M, Jallo G. Complications of CSF Shunting in Hydrocephalus.

Rui K, Ah J, Wolfe R, Danks A. Factors affecting the accuracy of ventricular catheter placement. J 
Clin Neurosci [Internet]. 2011

Tamber MS, Klimo P, Mazzola CA, Flannery AM. Pediatric hydrocephalus: systematic literature review and evidence-based guidelines. Part 8: Management of cerebrospinal fluid shunt infection. J Neurosurg Pediatr [Internet]. 2014;14(Suppl1):60-71.

Tisell M. Perioperative risk factors for short term shunt revisions in adult hydrocephalus patients. 2009;1248-53.

Tuli S, Drake J, Lawless J, Wigg M, Lamberti-Pasculli M. Risk factors for repeated cerebrospinal shunt failures in pediatric patients with hydrocephalus. J Neurosurg. 2000;92(1):31-8.

Wong T-T, Liang M-L, Chen H-H, Chang F-C. Hydrocephalus with brain tumors in children. Child's Nerv Syst [Internet]. 2011;27(10):1723-34. Available from: http://link.springer.com/10.1007/s00381-011-1523-9 